\title{
Film és rekreáció 1. - A pandémia árnyékában
}

\section{Film and recreation 1. - In the Shadow of the Covidl9 Pandemic}

\section{ÖSSZEFOGLALÁS:}

A Covid19 járvány miatti lezárásoknak és szabályozásoknak köszönhetően az életünk minden téren gyökeresen átalakult. Olyan szabadidős tevékenységeink, mint a filmszínházba járás, hónapokon át ellehetetlenült. A cikk betekintést ad az online szolgáltatók szférájába is, amely a multiszerkezetű 21 . századi filmpiac egyik szegmense, egy új (megerősödött?) filmnézési színtérként.

Kulcsszavak: világjárvány, rekreáció, mozik, online kultúra, SVoD

\section{ABSTRACT:}

Due to the restrictions caused by the Covid19 epidemic, our lives have been radically transformed in all areas. Leisure activities such as going to the movie theater have been impossible for months. This article provides insight also into the realm of online service providers, which is a segment of the multi-structured 21st century film market, as a new (strengthened?) movie-watching scene.

Keywords: pandemic, recreation, movies, online culture, SVoD

\section{BEVEZTÉS}

A „mozizás” a fogyasztói társadalom által kínált egyik olyan szolgáltatás, mely potenciális lehetőségét hordozza a kikapcsolódásnak, bár értéktartalmuk jelentősen különböző lehet (Patakiné Bösze, 2020). A mozifilmek nézése a szellemi rekreáció rendszerében (Fritz, 2019) a kulturális főcsoport szellemi alcsoportjához, és a Társasági, egyéni tevékenységeken belül az összejövetelek alá is besorolható.

Andorka (2006) definícióját követve az "életmód filmes dimenziója" így értelmezhető napjainkban: szükségleteink kielégítése érdekében, adott társadalmi rendszerben és korban elérhető film müfajok megtekintési módja társas és/vagy egyéni keretek között, különböző offline (fizikai) és online színtereken.

A filmnézési színterek az alábbiak szerint rendszerezhetők:

1. „hétköznapi” rekreációként és a turizmus keretében végzett filmnézés

Szerzö / rovatvezetö: DR. MAGYAR MÁRTON Egyetemi adjunktus ELTE Egészségfejlesztési és Sporttudományi Intézet 1117 Budapest, Bogdánfy Odön u. 10/B. magyar.marton@ppk.elte.hu Érdeklódési kör: animáció, turizmus, zene, tánc, úszás Fotó: Hámori Zsófia -gyártási helyszín, filmmúzeum, filmes tematikus park felkeresése, ám a filmfesztiválok is jelentős turistaszámot vonzanak (Irimiás, 2015) - pandémiamentes időben.

Az „offline” (fizikai) valóságban történő filmnézés klasszikus helyszíne a filmszínház, a mozi; emellett ún. alternatív lehetőségeket is találunk a kínálatban: drive-in (autósmozi), kertmozi, rooftop cinema, ágymozi (Gősi Magyar, 2019).

A virtuális térben történő filmnézés történhet lineáris (tv) és nem-lineáris szolgáltatók által. Ez utóbbiak közé tartozik a SVoD (Subscription Video on Demand), azaz előfizetéses, átalánydíjas lekérhető streaming videós szolgáltatás, amely mint egy videótéka múködik az igényeink szerint. Jellemző példái, amelyek hazánkban is ismertek: Netflix, HBO Go (HBO Max), Amazon Prime Video, Apple tv+ (és hamarosan a Disney Plus is).

\section{MÓDSZEREK}

Témaspecifikus források tartalomelemzésével kerül bemutatásra a tárgykör elméleti háttere, amely megalapozza a folytatásaként később megjelenő, kérdőives felmérésre alapozott tanulmányt is. A statisztikai adatok másodelemzése MS Excel szoftverrel, az adatsưrítés és szemléltetés pedig saját készítésű táblázatokkal történt.

A tanulmány célja az offline és virtuális filmnézés környezeti bemutatása a Covid19-járvány hatásait szemléltetve, valamint betekintés a streming videó nézés rekreációs vonatkozásaiba. 


\begin{tabular}{|c|c|c|}
\hline Év & $\begin{array}{c}\text { Mozi- } \\
\text { látogatás } \\
\text { (ezer) }\end{array}$ & $\begin{array}{c}\text { Változás az } \\
\text { elózö évhez } \\
\text { képest (VI\%) }\end{array}$ \\
\hline 2014 & 10336 & $\cdots$ \\
\hline 2015 & 12512 & $21,05 \%$ \\
\hline 2016 & 14293 & $14,23 \%$ \\
\hline 2017 & 14646 & $2,47 \%$ \\
\hline 2018 & 15477 & $5,67 \%$ \\
\hline 2019 & 15111 & $-2,36 \%$ \\
\hline 2020 & 4271 & $-71,74 \%$ \\
\hline
\end{tabular}

\begin{tabular}{|c|c|c|}
\hline Év & $\begin{array}{c}\text { Egy mozi-elōadásra } \\
\text { jutó látogatások } \\
\text { átlagos száma }\end{array}$ & $\begin{array}{c}\text { Változás az } \\
\text { elózó évhez } \\
\text { képest (VI\%) }\end{array}$ \\
\hline 2014 & 23 & --- \\
\hline 2015 & 26 & $14,53 \%$ \\
\hline 2016 & 29 & $10,51 \%$ \\
\hline 2017 & 31 & $6,59 \%$ \\
\hline 2018 & 29 & $-5,17 \%$ \\
\hline 2019 & 30 & $2,51 \%$ \\
\hline 2020 & 17 & $-43,64 \%$ \\
\hline
\end{tabular}

\begin{tabular}{|c|c|c|}
\hline Év & $\begin{array}{c}\text { Mozi- } \\
\text { elỏadás } \\
\text { (ezer) }\end{array}$ & $\begin{array}{c}\text { Változás az } \\
\text { elózó évhez } \\
\text { képest (VI\%) }\end{array}$ \\
\hline 2014 & 447 & --- \\
\hline 2015 & 475 & $6,26 \%$ \\
\hline 2016 & 491 & $3,37 \%$ \\
\hline 2017 & 472 & $-3,87 \%$ \\
\hline 2018 & 526 & $11,44 \%$ \\
\hline 2019 & 501 & $-4,75 \%$ \\
\hline 2020 & 257 & $-48,70 \%$ \\
\hline
\end{tabular}

1. ábra: Mozistatisztika Magyarországon (2014-2020)

Figure 1. Hungarian movie statistics (2014-2020): attendance number, average attendance number on a show; number of cinema shows Forrás/Source: KSH (2021) alapján saját szerkesztés, 2021 / Own redaction, 2021 by KSH (2021)

EREDMÉNYEK

\section{"OFFLINE" MOZIK}

A KSH (2021) statisztikáit áttekintve 2015-től dinamikus növekedés volt megfigyelhető a hazai mozilátogatások számában. A 2019. évi megtorpanást követően jelentős visszaesés tapasztalható hazánkban

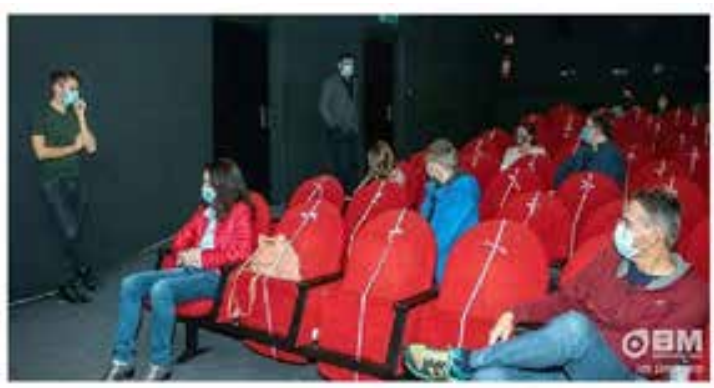

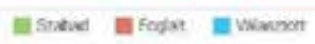

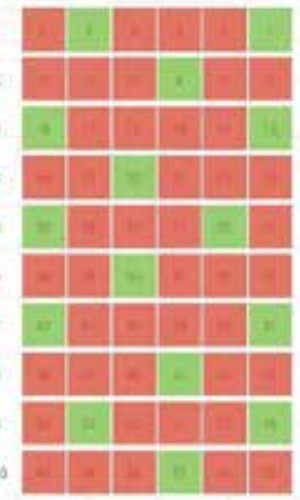

2. ábra: Maszkos, hiányos nézőtér és helyfoglalási rendszer a székesfehérvári Barátság moziban

Figure 2. Face-masked, uncrowded cinema au ditorium and reservation system (in Barátság Cinema of Szekesfehervar, Hungary)

Forrás/Source: https://baratsagmozi.hu/2020/11/min denkinek-megvan-a-maga-keresztje; www.facebook. com/baratsagmozi is: a koronavírus-járvány hatására bezárt filmszínházak látogatószáma közel háromnegyedével visszaesett, valamint közel felére csökkent a bemutatott filmek és az 1 előadásra jutó átlagos nézőszám is (1. ábra).

Az első hullám során a magyarországi mozik maximum 99 főt fogadhattak 2020. 03. 12-től (2020:41. Korm.rend.), majd 2020. 03. 17-től bezártak (2020:46. Korm.rend.). A veszélyhelyzet megszüntetését (2020:LVII. tv.) követő naptól, 2020. 06. 18-tól újra múködhettek pár hónapig. Az újbóli veszélyhelyzet kihirdetésétól, 2020. 11. 04-10. között minden 3 . ülőhelyen helyet foglalva lehetett mozifilmet nézni (2020:479. Korm.rend.), az egymás mellett és a különböző sorokban ülők között is lehetőség szerint 1,5 méteres távolságot megtartva (2. ábra).

A 2. és 3. hullám okozta a legnagyobb veszteséget a rekreáció ezen területén. Több lépcsőben oldották fel a korlátozásokat hazánkban: védettségi igazolvánnyal rendelkező felnőtteknek és a felügyeletük alatt álló kiskorúaknak újra lehetett látogatni a mozikat a 4 milliomodik beoltott után (2021:194. Korm. rend.), azaz 2021. 05. o1-től; majd az 5 milliomodik után a 16-18 éves beoltott fiatalok felnőtt kísérő nélkül is mehettek moziba, színházba (2021:264. Korm.rend.), azaz 2021. 05. 24-től. Végül a kötelező beltéri maszkhasználatot is eltörölték az 5,5 millió beoltott elérésével (2021:365. Korm.rend.) és védettségi igazolvány sem szükséges a mozikban sem, 2021.07.03-tól.
Európában nem volt egységes helyzet. Volt, ahol nyitva voltak a mozik: Horvátország, illetve Bosznia és Hercegovina területén az intézkedéseket figyelembevéve; Csehország, Észtország (50\%), Koszovó (vetítések 18.oo-ig), Luxemburg, Montenegró (vetítések 21.oo-ig), Portugália (7 település kivételével), Románia (70\%-os kapacitás), Spanyolország (regionális korlátozásokkal), Svédország ( $\max .8$ fö,június 1-től 50 fó), Svájc (max. 26 fó, vagy 50\% június 26-tól).

Többségében május és június hónap során nyíltak újra a mozik 10 EU-országban (1. táblázat).

Franciaországban többlépcsős újranyitás történt: május 19. (35\%, 21:OO kijárási tilalom); június 9. (65\%, 23:0o kijárási tilalom); június 30-tól 100\%-os kapacitással, kijárási tilalom nélkül (Cineuropa, 2021).

\section{VIRTUÁLlLS MOZI}

Az ellehetetlenült fizikai mozilátogatás hatására a filmek és sorozatok iránti igények kielégítése az otthonokba költözött. Egy, a járvány első hulláma alatt készült rekreációs tevékenységeket vizsgáló ELTE-kutatás $(N=381$, nő=67\%) rámutatott arra, hogy jelentősen felértékelődött a tv- és filmnézés: a korlátozások előtt a válaszadók 3,4\%-a fordított több mint 3 órát ezekre a tevékenységekre, míg ugyanez az intenzitás a korlátozások alatt 9,4\%-ra emelkedett. Magas a 2-3 órás időtöltés változása is: 8,9-ről 19,2\%-ra (Gősi, 2020). 


\begin{tabular}{|c|c|c|c|}
\hline \multicolumn{2}{|c|}{ Újranyitás } & \multirow{2}{*}{ Ország } & \multirow{2}{*}{ Specialitás } \\
\hline hónapja & napja & & \\
\hline \multirow{4}{*}{ 2021. április } & 1. & Bulgária & $30 \%$-os kapacitással \\
\hline & 9. & Litvánia & \\
\hline & 23. & Szlovénia & 50\%-0s kapacitással, védettek, negatív Covid-teszt \\
\hline & 26. & Olaszország & a közepes kockázatú régí́kban (.sárga zónák") \\
\hline \multirow{5}{*}{ 2021. május } & 6. & Dánia & max. 500 fö, védett, helykihagyás \\
\hline & 7. & Norvégia & $\max .50$ fó, június 15-tốl max. 200 fô \\
\hline & 17. & Szlovákia & korlátozásokkal \\
\hline & 21. & Görögország & szabadtéri mozik \\
\hline & 21. & Lengyelorság & \\
\hline \multirow{5}{*}{ 2021. június } & 4. & Németorszig & Covid-teszttel \\
\hline & 5. & Hollandia & \\
\hline & 7. & Írország & \\
\hline & 9. & Belgium & $\max .200$ fövel \\
\hline & 10. & Cschország & Multiplex mozik \\
\hline
\end{tabular}

1. táblázat: Európai mozik 2021. évi újranyitása időrendi sorrendben

Table 1. Reopening of cinemas in 2021 in Europe

Forrás/Source: Cineuropa (2021) alapján saját szerkesztés, 2021 / Own redaction, 2021 by Cineuropa (2021)

A 18-32 éves korosztály körében, 2020 szeptemberében végzett Ipsos-kutatás ( $N=1000$, nem, kor és településtípus szerint reprezentatív minta) pedig azt mutatta ki, hogy a napi többszöri televíziózás szokása inkább a gyermekes családok (41\%) és az alacsonyabb költési hajlandósággal rendelkezők (45\%) körében jellemző. A nemek között nem fedezhető fel szignifikáns különbség a tv-nézés gyakoriságában. Videós tartalmak megtekintéséhez az SVoD-előfizetés számottevő a budapesti (54\%), felsőfokú végzettségű (45\%), és a relatíve jobb anyagi helyzetben lévő (47\%) személyek körében. Tv-ben filmet 26\%, sorozatot 22\% néz meg; míg streamelt vagy torrentról letöltött formában 53 és 57\%-uk (MEME, 2020). Hasonlóan a tv-hez, a korábbi jelentős fogyasztási módok, mint a DVD és a BlueRay formátum is már évek óta marginalizálódott, mivel kevesebb hozamot eredményeznek, mint az előfizetéses streaming szolgáltatás (Squire, 2017 idézi Gaustad, 2019).

Az SVoD-szolgáltatók között úttörőnek, piacvezetőnek számít a Netflix, amely 1997-ben alapult az USAban mint DVD lemezeket értékesítő és kölcsönző cég. A 2000-es években online értékesítési és kölcsönzési kezdeményezéseket vezetett be, kategorizálva a nézői preferenciákat és szokásokat (Rolf, 2017idézi Orman$l$, 2019). 2000-ben 300.000, 2 évvel késóbb 600.000, 2005-ben peelőfizetéses lekérhető streaming videós szolgáltatás az egyes életkori
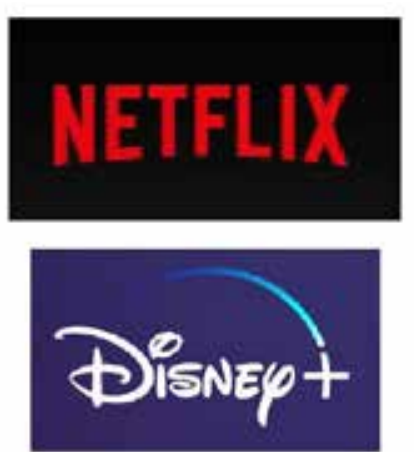

\section{3. ábra: SVoD-szolgáltatók}

Figure 3. SVoD providers kohorszokban. Mégis milyen (rekreációs) előnyök és hátrányok fedezhetők fel számukra ebben a tartalomfogyasztásban?

A Netflix egyik sikere, hogy hatalmas mennyiségú adatot gyưjtve a sokféle előfizetőtől (tartózkodási hely, megtekintett tartalom, előzetesen beállított érdeklődés, valamint a felhasználó által keresett adatok és a felhasználó filmnézési ideje), ezek alapján speciális algoritmusa által személyre szabott ajánlatokat nyújt (Maddodi - Krishna Prasad, 2020).

$\mathrm{Az}$ otthoni film/videónézés elönyei között említhető a reklámmentes, megállítható, újranézhető filmnézés lehetősége, a premierfilmek korábbi megtekintésének lehetősége (a tv-hez képest), valamint a sorozatok epizódjainak egyhuzamban történő megtekintése. Bár korábban volt olyan szolgáltató, amely az epizódokat 1 hét különbséggel sugározta. Az egyedi igények a müfajok tekintetében is könnyebben kielégíthetők. Fajlagosan olcsóbban tekinthető meg az SVoD-előfizetéssel egy-egy film. Az utazási idő megtakarításával, a szabadabb otthoni időbeosztással akár délelőtt, délután vagy este is megtekinthetók a filmek, akár több is. A szolgáltató képes „megjegyezni”, hol hagytuk abba a filmet, s legközelebb onnan folytathatjuk. Kényelmesebb környezetben tekinthetjük meg a filmet, mint
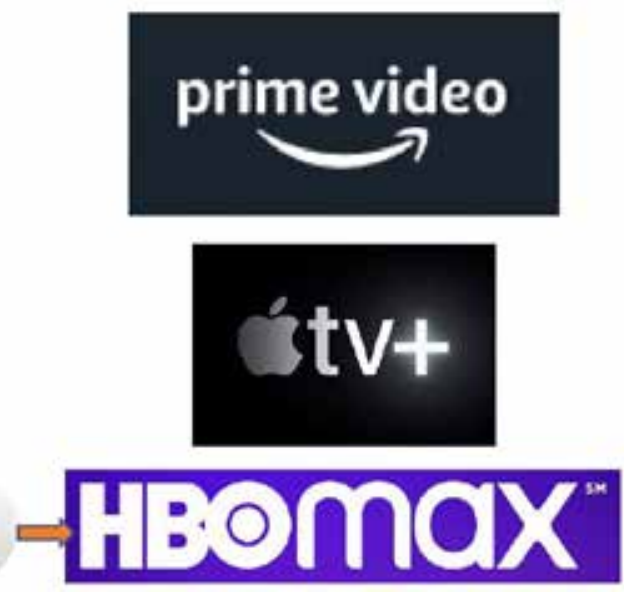

Forrás/Source: www.netflix.com; www.primevideo.com; www.preview.disneyplus.com/hu; https://hasznaltalma.hu/apple-hirek/2019/03/27/bemutatkozik-az-apple-tv-a-vilag-legkreativabb-tortenetmeseloinek-uj-otthona-rp; https://hu.ign.com/hbo-max/63553/news/kiderult-mikores-hogyan-startolhat-el-az-hbo-max-magyarorszagon 
a moziszékek. Az vélhetően szintén többek számára a virtuális mozi javára billenti a mérleget, hogy nem áll fel előttünk senki a nézőtéren, így kitakarva egy részét az éppen játszódó jelenetnek.

Hátrányok is említhetők természetesen, a teljesség igénye nélkül: több esetben eredeti nyelven magyar felirattal tekinthetôk meg a müsorok, amelyek néhány néző számára nehézséget okozhatnak; az árérzékenység tükrében a csomagválasztással és a regionális elérhetőség miatt korlátozott kínálatból válogathatunk. Egy idő után eltünhetnek (kedvenc) filmjeink a tékából. A közösségi filmnézésből fakadó előnyök is eltúnhetnek, mint a közös kacagás. Bár ez is lehet zavaró tényező valaki számára az „offline” moziban. Habár a megtekintett filmmel kapcsolatos érzések, tapasztalatok virtuális közösségek felületein, online írásbeli és szóbeli csevegésben is megvitathatók, ezek is más érzelmi outputot eredményezhetnek, mint élőben (virtuális kifejezőképességünk eltérő lehet a verbálistól). Ezzel a módszerrel könnyebben kerülhet a néző digitális függőségbe, esetleg a társadalmi kapcsolatai terén is anomáliák következhetnek be. Akik a fizikai mozik monumentális hanghatásait kedvelik, házimozi-rendszer hiányában kevésbé tudják ezt az élményt otthonukban átélni.

\section{KÖVETKEZTETÉSEK}

Az év közel 2/3-ában múködni képes mozik a járványhelyzet miatt a korábbi nézőszám mintegy 30\%-át tudták csak elérni. Ez a változás vezethetett oda, hogy a virtuális térben történő filmnézés óriási mértékủ bővülést érhetett el, hazánkban is. Habár a bezártság érzete számos emberben negatív érzeteket keltett, a filmnézés egy új és bizonyos előnyöket is magába foglaló színtérrel gazdagodott. Az online mozi további térhódítása, helytállása csak késóbb, a járvány végleges megszünte után lesz megállapítható. Ám vélhetően ez is megtartja létjogosultságát a piacon, mint például a home-office vagy a távolléti oktatás.

\section{IRODALOMJEGYZÉK}

2020:41. (III.11.) Korm.rend. az életés vagyonbiztonságot veszélyeztető tömeges megbetegedést okozó humánjárvány megelőzése, illetve következményeinek elhárítása, a magyar állampolgárok egészségének és életének megóvása érdekében elrendelt veszélyhelyzet során teendő intézkedésekről. Magyar Közlöny. 2020/40. 1356-1358. o.

2020:46. (III.16.) Korm.rend. az életés vagyonbiztonságot veszélyeztető tömeges megbetegedést okozó humánjárvány megelőzése, illetve következményeinek elhárítása, a magyar állampolgárok egészségének és életének megóvása érdekében elrendelt veszélyhelyzet során teendő intézkedésekről (III.). Magyar Közlöny. 2020/45. 14441446. 0.

2020:479. (XI.3.) Korm.rend. a veszélyhelyzet idején alkalmazandó további védelmi intézkedésekről. Magyar Közlöny. 2020/237. 7573-7576. o.

2020:LVII. tv. 2020. évi LVII. törvény a veszélyhelyzet megszüntetéséről. Magyar Közlöny. 2020/144. 3652-3652. o.

2021:194. (IV.26.) Korm.rend. a védelmi intézkedések lépcsőzetes feloldásának harmadik fokozatára tekintettel a veszélyhelyzet idején alkalmazandó védelmi intézkedéseket szabályozó kormányrendeletek módosításáról. Magyar Közlöny. 2021/68. 2634-7576. o.

2021:264. (V.21.) Korm.rend. a védelmi intézkedések lépcsőzetes feloldásának ötödik fokozatára tekintettel a veszélyhelyzet idején alkalmazandó védelmi intézkedéseket szabályozó kormányrendeletek módosításáról. Magyar Közlöny. 2021/94. 3787-3792. o.

2021:365. (VI.30.) a védelmi intézkedések lépcsőzetes feloldásának hatodik fokozatára tekintettel a veszélyhelyzet idején alkalmazandó védelmi intézkedéseket szabályozó kormányrendeletek módosításáról. Magyar Közlöny. 2021/123. 5781-5784. o.

Andorka, R. (2006) Bevezetés a szociológiába. Osiris Kiadó, Budapest

Cineuropa (2021) The European film industry finds its way through the latter stages of the coronavirus pandemic. From: https://cineuropa.org/en/newsdetail/394354
Fritz, P. (2019) A rekreáció fogalma, rendszertani felosztása. In: Fritz, P. (szerk.): Alapfogalmak és jelentéseik a rekreáció területén: Rekreáció mindenkinek III. Miskolci Egyetemi Kiadó, Miskolc, 29-41. o.

Gaustad, T. (2019) How streaming services make cinema more important. Nordic Journal of Media Studies. 1. 1. 67-84. DOI: 10.2478/njms-2019-0005

Gősi, Zs. - Magyar, M. (2019) Alternatív mozi élmények. Recreation. 9. 3. 30-32. o. DOI: 10.21486/recreation.2019.9.3.3

Gősi, Zs. (2020) Rekreáció a korlátozások alatt. In: Fokasz, N., Kiss, Zs., Vajda, J. (szerk.) Koronavírus idején. Replika Alapítvány, Budapest, 29-36. o.

Iqbal, M. (2021) Netflix Revenue and Usage Statistics (2021). From: https:// www.businessofapps.com/data/netflix-statistics

Irimiás, A. (2015) Filmturizmus - A filmek és televíziós sorozatok turisztikai szerepének és hatásainak geográfiai vizsgálata. Akadémiai Kiadó, Budapest

KSH (2021) Mozik, filmek. From: http://www.ksh.hu/stadat_files/ksp/hu/ ksp0016.html

Maddodi, S., Krishna Prasad, K. (2020) Netflix Bigdata Analytics - The Emergence of Data Driven Recommendation. International Journal of Case Studies in Business, IT, and Education. 3. (2). 42-51. DOI: org/10.5281/zenodo.3510316

MEME / Magyar Elektronikus Müsorszolgáltatók Egyesülete (2020) Az életkor előrehaladtával változó médiafogyasztási szokások vizsgálata. 2. szakasz (Primer kutatás). Kutatási jelentés a MEME részére. 2020. október 26. From: https://www.memeinfo.hu/system/ files/researches/attachments/ipsos_-_ meme_kohorsz_kutatas_ii._2020_hun_ final.pptx

Ormanl, O. (2019) Online Film Platforms and the Future of the Cinema. In: Yengin, D., Algül, A. (Eds.) CTC 2019 (Communication and Technology Congress 17th April 2019) Papers. Bologna, Italy: Editografica s.r.l., 229-236. DOI: 10.7456/ctc_2019_19

Patakiné Bősze, J. (2020) Az alternatívák keresése a rekreációban, avagy az életminőség feltételcsoportjai a 21 . században. In: Gősi, Zs.; Bárdos, Gy.; Magyar, M. (szerk.) Sokszínű rekreáció II.: Egészségmegőrzés - Életkorok - Képzés. Akadémiai Kiadó, Budapest, 41-60. o. 